\title{
The Pauline methodology of communicating the Word to a gentile audience
}

\author{
Dr. Mike Megrove Reddy (D.Litt.) \\ Department of Communication \\ University of Zululand, South Africa \\ E-mail: ReddyMM@unizulu.ac.za \\ DOI: https://doi.org/10.46222/pharosjot.102.037
}

\begin{abstract}
The article describes and reconnoitres how the Apostle Paul, a Hebrew who was a welllearned man and a brilliant scholar and studentunder Gamaliel, went about conveying the Word to the Gentiles. The aim of this brief study is thus to describe the methodology used by the Apostle Paul to communicate the Word. He was raised to leadership and mentorship and gave guidance to the body of Christ and used every form of communication at his disposal to share the gospel with the surrounding Gentile world. Though he was called to preach the word of God to the Gentiles, he also preached to the Jews and defended the gospel against various kinds of obstinate and pagan rulers. The New Testament ('H Kaıvì $\Delta ı$ a of the letters written by the Apostle Paul. It should also be noted that although he was a prolific writer and teacher of the word, Paul encountered many barriers when it came to sharing the gospel.
\end{abstract}

He was nonetheless very able to connect with people in the Graeco-Roman world outside of his culture and could easily communicate with the intellectual élites he encountered in the Empire. He was an eloquent speaker and also engaged effectively with the non-believers in the promulgation of the gospel message. Paul allowed both give-and-take, he was always eager to answer acute questions on faith issues, and he exerted himself in aiding people to acknowledge the truth of Jesus Christ. At times Paul spent a short period of time in a city, presenting the gospel and opening new churches. However, in Acts 18:11, it is evident that Paul stayed at one place for up to a year and time was spent in instructing the locals and also in evangelizing. This was clearly a sound strategy designed to meet his objective. In the Graeco-Roman culture, Paul personified a strong voice present in his oral and written works. The theoretical framework used in this study was the Shannon and Weaver Communication Model. This paper was based on a desktop research approach and literature from various sources was used including holy scriptures, academic articles, books, and various online sources.

Keywords: Christianity, Apostle Paul, communication, verbal communication, small group communication, and written communication.

\section{Introduction and Background}

The Apostle was a Pharisee and was well trained in the scriptures and mentions he studied under Gamaliel a well-known teacher of his day. "The Roman Empire laid the way open for Christianity to become a world religion" (Reddy, 2002, 75). It is evident that during the reign of Augustus, there existed barriers of race and nationality but these were obliterated, travel was easier, peace was permanent and everything was favourable for a worldwide mission (Reddy, 2002). Had the Roman government been actively hostile to Christianity from the start, the advantages of the Roman rules would have been nullified. At the time of Christianity, the Roman world had been so developed, it made travel much easier and also safer. This made the spreading of the gospel much easier. 
Since Old Testament times, communication played a vital role in interacting and not just between humans, but also between God and humans and even angels and humans. There are instances of God speaking with a man (Moses and God, Exodus 3: 1-6) and there are also instances of angels speaking with a woman, for example, the angel and Mary before she was to be with the child Jesus (Luke 1: 26-38).

By studying the scriptures (Acts 22: 3), the Apostle Paul became the ideal candidate to lay the foundation and grounding for the church. We are reminded of Moses who studied in the house of Pharaoh and became the ideal candidate for God to use to write the first five books of the Bible, the Torah. According to Acts 7: 22 "Moses was educated in all the wisdom of the Egyptians and was powerful in speech and action." Likewise, Paul studied under Gamaliel and was knowledgeable about the Old Testament. This knowledge he shared through every form of communication available to him to share the gospel. Among the variosi communication forms were verbal, downward, upward, horizontal, small group communication, public communication, confrontational communication, and written communication.

\section{Theoretical Framework}

Figure 1

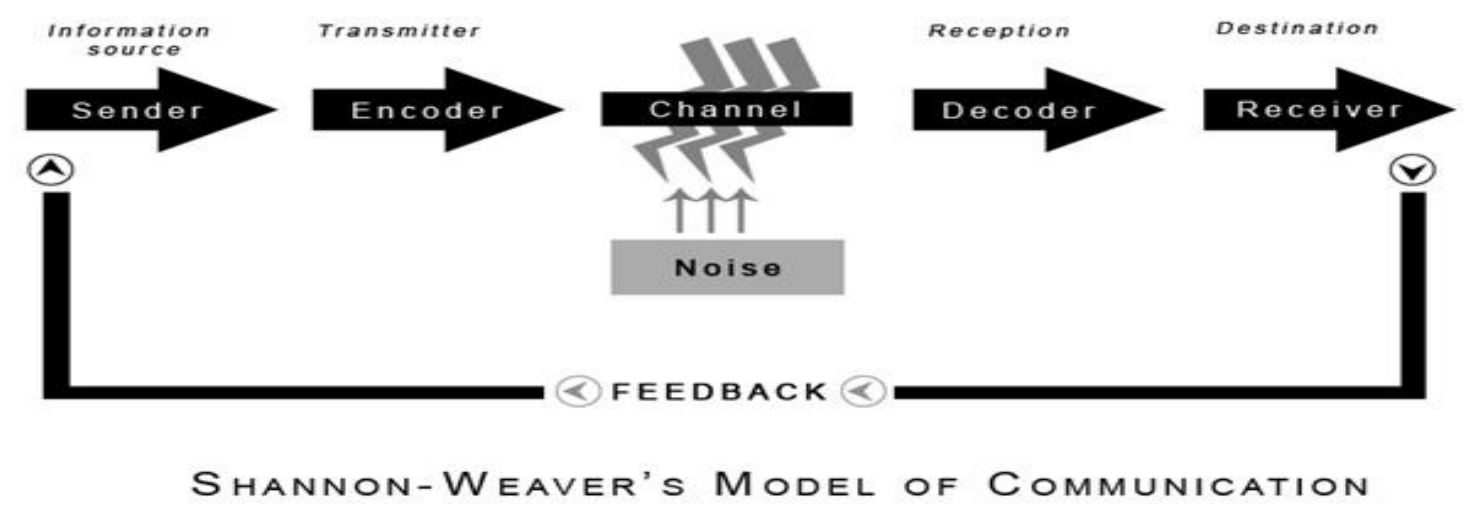

Taken from https://www.communicationtheory.org/shannon-and-weaver-model-of-communication/.

The Theoretical Framework preferred and used in this article is the Shannon and Weaver Model of Communication. In this model, the sender encodes the message before they send the message. They use a specific medium to transit the message. The receiver needs to decode the message. However, it is only through feedback that the sender will be able to conclude if the receiver understood the intended message. At times, there will be what we call 'noise' which hinders the communication process, or barriers. Barriers are the hindrances that cause stumbling blocks when receiving a message (Reddy, 2021). Put into the context of this paper, the sender will be the Apostle Paul. The sender, when applied to the Apostle Paul will be the user of verbal communication, interpersonal communication, small group communication, mass communication, confrontational communication, and written communication. The receiver will be his audience - at times it was those within synagogues, those who would listen to the Apostle Paul and those who would read his letters and those who would listen to others reading the Apostle Paul's letters to them. The Apostle Paul initially wrote to a set person or audience. However, within Christianity as an organisation, this could be seen as a barrier as only one copy of a communication in the form of a letter was made. In time these letters were copied and sent to other individuals and churches, making the Apostle Paul's message reach a far larger audience. "And when Saul had come to Jerusalem, he tried to join the disciples, but they were all afraid of him, and did not believe that he was a disciple" (Acts 9: 26). The other apostles did not believe that he had become a disciple of the Lord and saw him as using the gospel as a means to have them arrested. The other Apostle could not believe that the persecutor of the gospel had become a preacher of the gospel so they chose not to believe in his sudden change of heart and therefore didn't want to be close to him. This 
became a barrier to the Apostle Paul. The Apostle Paul's major barrier was that most of the times he was not free to preach whenever and wherever he preached he was in constant threat of death from Jews, Romans or Gentiles (2 Corinthians 11:26).

\section{Who was the Apostle Paul?}

Apostle Paul was born in CE 5, Tarsus, Cilicia. He was initially known as Saul of Tarsus. The Hebrew word for Saul is שאול In Biblical Greek, Saul is written as $\Sigma$ ¿ũ̃os (Saulos). The name Saul means 'dedicated to God'. The Apostle Paul was a Roman citizen. He stated that he was "circumcised on the eighth day, of the people of Israel, of the tribe of Benjamin, a Hebrew of Hebrews; in regards to the law, a Pharisee; ${ }^{6}$ as for zeal, persecuting the church; as for righteousness based on the law, faultless" (Philippians 3: 5-6). He stated "I am a Jew, born in Tarsus of Cilicia, but brought up in this city. I studied under Gamaliel and was thoroughly trained in the law of our ancestors. I was just as zealous for God as many of you are today" (Acts 22: 3). These were the words of the Apostle Paul as recorded by Luke in the book of Acts. Gamaliel was the most learned man of his day. It was this type of training for Paul as a Pharisee which enabled him to enter the synagogue whenever he needed. He also learned tent-making as a trade (Acts 18: 3 ).

He was known first as Saul 'the persecutor of the people of the Way'. However, after his encounter with Christ, he became known as Paul the preacher of the gospel of Jesus. Whilst on his way to destroy the people of the Way, he had a divine encounter with Christ on the street called Straight (Acts 9: 18). This encounter left him blind but transformed him instantly. He received his sight after he was prayed for by Ananias (Greek: Avavías) and he was baptised (Acts 9: 18). The church of Antioch was instructed by the Holy Spirit to send Paul and Barnabas (Greek: Bapváßas) into the mission field (Acts 13: 1-3). Saul was called Paul for the first time while he was on the island of Cyprus (Acts 13: 9). Biblical Greek: Пaũ (Paulos). He preached not only to the Gentiles, but also to the Jews and was brought before rulers during his trial (Felix in Acts 24, Festus in Acts 25, and Agrippa, Acts 25: 23 to Acts 26). Following his arrest in Jerusalem, he was sent to Rome (Acts 21:27, 28: 16-31). According to Christian tradition, he was released from prison following further missionary work, rearrested, imprisoned again in Rome, and beheaded outside the city.

The Apostle Paul took the gospel to the Gentiles (Galatians 2: 7-10) and preached in the synagogues and to the Jews. Heeven spoke up for the church at the Council of Jerusalem (Acts 15: 1-18) and also embarked on three extended missionary journeys (Acts 13-20). He founded many churches throughout his life. The Book of Acts mentions six sermons were preached by the Apostle Paul (Acts 13: 14-43, 17: 22-31, 20:17-38, 22: 1-22, 24: 10-21, 26 : 1-24). In his letter to the Romans, he stated that he wanted to visit Rome (Romans 15: 24, 28). Paul wrote letters to numerous churches and individuals, which are in the New Testament. He however also used various other forms of communication to maintain and propagate the gospel to the early church adherents.

\section{The Apostle Paul an Apostle to the Gentiles}

According to Romans 11:13, the Apostle Paul calls himself "....an apostle to the Gentiles". The Apostle Paul at times preached to Jews especially when he entered a new city, and he preached in synogues (Acts 17:2). The other apostles also preached to the Gentiles. However, it should be noted that the Apostle Paul's ministry was unique and special. In Romans 15: 1516, Paul states "15yet I have written to you quite boldly on some points to remind you of them again, because of the grace God gave me ${ }^{16}$ to be a minister of Christ Jesus to the Gentiles. He gave me the priestly duty of proclaiming the gospel of God so that the Gentiles might become an offering acceptable to God, sanctified by the Holy Spirit." During the Apostle Paul's court 
case in Caesarea, he used Koine Greek, when speaking to Agrippa and Fetus and this shows us hoe knowledge of the language of the day (Acts 25: 14-22, 26: 1-29) (Spencer, 2017).

According to Galatians 1:15-16, the Apostle Paul was set apart since birth and called by the grace of God so he could preach the gospel to the Gentiles. Luke states in the Book of Acts (9:15) what God required of Ananias and it is stated as follows: "But the Lord said to Ananias, "Go! This man is my chosen instrument to proclaim my name to the Gentiles and their kings and the people of Israel."

Reddy (2017: 190) states "In looking at the writings of Paul, one will notice that he mentions his name in the introduction of his letters so that his audience will know that the letters were from him (See table 1. Colossians 1: 1, Philippians 1: 1, Ephesians 1: 1, etc.). He maximised the use of written communication (Kim, 2011). He dedicated it to an amanuensis or secretary (Romans 16: 22, such a person is named as Tertius). However, the final sections of the letters were penned by the Apostle Paul (Colossians 4: 18, Galatians 6: 11, 1 Thessalonians. 3: 17, etc.)."

Table 1. The Pauline Epistles

\begin{tabular}{|c|c|c|}
\hline Epistle name & Recipients of letter & Greek name \\
\hline Romans & The Church at Rome & Прò ${ }^{\mathrm{P}} \mathrm{P} \omega \mu \alpha$ íovs \\
\hline First Corinthians & The Church at Corinth & 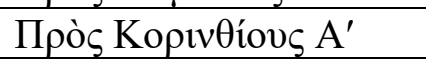 \\
\hline Second Corinthians & The Church at Corinth & 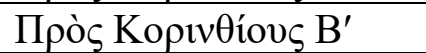 \\
\hline Galatians & The Church at Galatia & 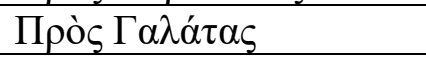 \\
\hline Ephesians & The Church at Ephesus & 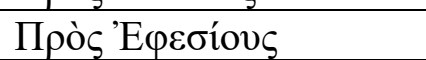 \\
\hline Philippians & The Church at Philippi & 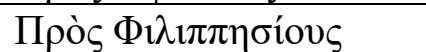 \\
\hline Colossians & The Church at Colossae & 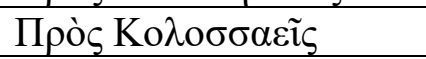 \\
\hline First Thessalonians & The Church at Thessalonica & 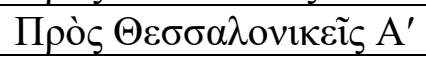 \\
\hline Second Thessalonians & The Church at Thessalonica & Прò $\Theta \varepsilon \sigma \sigma \alpha \lambda o v ı \kappa \varepsilon i ̄ \varsigma ~ B^{\prime}$ \\
\hline First Timothy & Timothy & 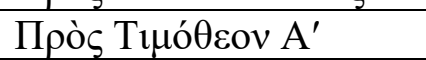 \\
\hline Second Timothy & Timothy & Прò $\varsigma$ T $1 \mu o ́ \theta \varepsilon o v \mathrm{~B}^{\prime}$ \\
\hline Titus & Titus & Прòs Tícov \\
\hline Philemon & Philemon & 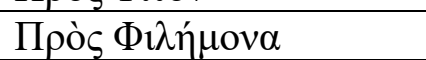 \\
\hline Hebrews & Hebrew devotees & 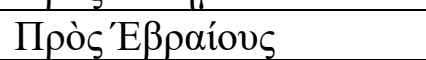 \\
\hline
\end{tabular}

\section{Forms of Communications used by the Apostle Paul}

The Apostle Paul had used various forms of communication which were available during his days to maintain and propagate the gospel of Christ. Among them were verbal, small group communication, organisational communication, intercultural communication, to mention a few. Since he was grounded in the word and was an expert in the law as written by Moses, he was able to become an exceptional defender of the gospel. Many would regard Paul as the Moses of the New Testament, for Moses gave the foundation of Judaism, likewise, the Apostle Paul laid the foundation for Christianity. He was surely a prolific writer to either individuals or to churches in the Graeco-Roman world. For example rrom Corinth in Greece, he wrote the lengthiest single letter in the New Testament, which he addressed to "God's beloved in Rome" (1:7). Like most New Testament letters, this letter is known by the name of its beneficiaries

Interpersonal Communication: It is communication between two individuals. This form of communication was used when the Apostle Paul was communicating with the other believers and non-believers and even apostles and when he was interacting with those who visited him in prison. An example of engaging with non-believers can be seen in, Acts 17: 22 "Paul stood in the middle of the Areopagus, and said, 'You men of Athens, I perceive that you are very 
religious in all things. For as I passed along, and observed the objects of your worship, I found also an altar with this inscription: 'TO AN UNKNOWN GOD.'”

Small Group Communication: Small groups are groups that consist of between 3 and 12 people. However, the ideal number will be between seven and nine members. Small group communication will be communication that takes place within such groups (Reddy, 2002, 2004, 2021).

Horizontal Communication: This is also known as lateral communication. It refers to communication that takes place between people on the similar or same level. It is regarded as effective communication. It is a form of communication that generally takes place between individuals of equal status, for example, worker-to-worker, manager-to-manager, Sunday school Teacher-to-Sunday school teacher, and apostles-to-apostles. This form of communication is used more often than upward communication (Reddy, 2002). This is evident, for example, when the Apostle Paul was speaking with the other apostles.

Upward Communication: This is also known as vertical communication. This form of communication occurs often less frequently when compared to downward communication. Upward communication is between a junior and a senior. At the time when the Apostle Paul joined the people of the Way, he joined Barnabas. At that moment Barnabas would have been like his mentor. So when he spoke to Barnabas it would be regarded as upward communication.

Downward communication: "Downward communication is when superiors disseminate information to their subordinates. However, the subordinate can only communicate with a superior when they are directed. This form of communication occurs more frequently than upward communication" (Reddy, 2004: 45). This would be when the Apostle Paul wrote to both of his understudies, Timothy and Titus (1 Timothy, 2 Timothy, and Titus).

Intercultural communication: According to Reddy (2004: 35) "Intercultural communication is communication among people of different cultures." Tubbs and Moss (1978: 8) quote Samovar and Porter "Whenever the parties to a communication act bring with them different experiential backgrounds that reflect a longstanding deposit of group experience, knowledge, and values we have intercultural communication." The Apostle Paul communicated verbally and publically with people from different cultures, for example he is regarded as the apostle to the Gentiles. A unique intercultural communication method used bythe Apostle Paul was to embrace cultural values and systems without compromising his values and principles. The Apostle Paul stated "20To the Jews I became like a Jew, to win the Jews. To those under the law, I became like one under the law (though I am not under the law), to win those under the law. ${ }^{21}$ To those not having the law I became like one not having the law (though I am not free from God's law but am under Christ's law), to win those not having the law. ${ }^{22}$ To the weak I became weak, to win the weak. I have become all things to all people so that by all possible means I might save some" (1 Corinthians 9:20-22). He immersed himsled in the culture of other race groups so that sharing the gospel with those groups became easier.

Grapevine: Reddy (2004: 34) states "The grapevine is also known as word of mouth communication. Information that is communicated through the grapevine can be verified." Information of the Lord would have been passed on from the Apostle Paul to other believers via the so called 'grapevine'.

Gender communication: Reddy (2004: 33) states "Gender communication focuses on how the accepted forms of communication disenfranchise females because it makes typical male assumptions. Gender communication also focuses on the different preferred ways when men and women communicate between gender groups and across gender groups. Such examples are when male singular pronouns he/him are used in general to refer to men and women." 
" 8 Now he who plants and he who waters are one, and each one will receive his reward according to his own labor" (1 Corinthians 3: 8).

Hearsay: The Oxford Advanced Dictionary of Current English states the definition of hearsay as follows, "common talk; rumor; what one has heard another person or other person say: I don't believe it; it's merely hearsay. Hearsay evidence is not accepted in law courts." A good example of this is seen in the Apostle Paul's writings to the church in Corinth (1 Corinthians. 15: 3-8) "3For what I received I passed on to you as of first importance ${ }^{[a]}$ : that Christ died for our sins according to the Scriptures, ${ }^{4}$ that he was buried, that he was raised on the third day according to the Scriptures, ${ }^{5}$ and that he appeared to Cephas, ${ }^{[b]}$ and then to the Twelve. ${ }^{6}$ After that, he appeared to more than five hundred of the brothers and sisters at the same time, most of whom are still living, though some have fallen asleep. ${ }^{7}$ Then he appeared to James, then to all the apostles, ${ }^{8}$ and last of all he appeared to me also, as to one abnormally born."

Public Speaking: This is when an individual addresses a large crowd of people such as when Paul preached in the synagogues. Acts 19: 8 states that "Paul entered the synagogue and spoke boldly there for three months, arguing persuasively about the kingdom of God." Showing that he often spoke at public venues. "Paul was intelligent and capable of crafting strong, persuasive arguments. You can see this in his discussion with the Athenian philosophers (Acts 17: 16-34), or any of his epistles. But when push came to shove, it was all about Jesus" (Jesus Film Project, n.d., n.p). This shows that he did not only engage in monologues and dialogues.

Confrontational communication: There was also confrontational communication that became evident between the Apostle Peter and the Apostle Paul. During a time when the Apostle Peter was eating with the Gentiles, when some Jews came, he left to go and sit with the Jews. The Apostle Paul rebuked him in the presence of everyone because of what he had done (Galatians 2: 11-21). Another example of a confrontation was when the Apostle Paul and Barnabas had a serious disagreement when it came to John Mark. The Apostle Paul was not in favour of Mark joining them again on their missionary trip and it ended up in them going their separate ways (Acts 15: 36-41). These two incidents are perfect examples of confrontational communication.

\section{The Written Communication of the Apostle Paul}

"Though the Christian movement preferred orality as its repository for sacred stories, its leaders freely employed the art of writing" (Ward, 1996, n.p). A message is often expressed in writing because a spoken message is impossible at a set time. The Apostle Paul wrote letters because he was unable to speak to his intended audience all the time. Though there are 27 books in the New Testament, 13 are attributed to Apostle Paul. Some attributed the Book of Hebrew to the Apostle Paul, however, he does not mention his name in the letter. His letters are not set out in the New Testament based on their chronological order (Murphy-O'Connor, 1995). For example the Book of Romans was used as the linking book between the Book of Acts and the other letters that are in the New Testament. Sarah Ruden, in her book Paul Among the People The Apostle Reinterpreted and Reimagined in His Own Time, (2010), argues for example, that in the letter to Philemon, Paul fashioned the Western idea of all people as being, "...unconditionally precious to God and therefore entitled to the consideration of other human beings".

\section{The Letter to the Romans}

He wrote this letter between CE 56-58 while he was in Corinth. It is regarded as one of the most influential writings of the Apostle Paul. This letter is addressed to the Christians in Rome and he hoped to visit them on his way to Spain. However, he was using this letter to make himself known to the church. 
In such ways, the Apostle Paul preached and taught the word of God and also promoted his writings. He was an excellent public relations specialist when it came to maintaining and propagating the gospel of Christ. All the Gentile churches beside the ones in Colossae and Rome were founded by the Apostle Paul. McGee (n.d.) states "Roman is peculiarly the Apostle Paul's proclamation of the global gospel. It is at once his defence, his apology, and his explanation of the gospel. The Holy Spirit prepared the man and gave him his message." However, he set forth a full statement. A systematic explanation of Christianity and the explanation of salvation are found in the first eleven chapters. The Apostle Paul thereafter explains how Christians are to conduct their lives (Reddy, 2002). According to Petruzzello (n.d.: n.p.) "The epistle is the longest and doctrinally most significant of St. Paul's writings and is more of a theological treatise than a letter. In it, he acknowledges the unique religious heritage of the Jews (before his conversion, Paul was a Jew and an ex Pharisee but asserts that righteousness no longer comes through the Mosaic Law but through Christ." Therefore, it is evident that righteousness is the theme of this letter.

\section{The First Letter to the Corinthians}

Corinth was destroyed by the Romans in 146 BCE but was rebuilt between 50-52 BCE by the Emperor Julius Caesar. This city was the centre of economic and political importance. The Apostle identifies himself as the author (1 Corinthians 1:1). It was written between CE 55-56. It was written during his three-year ministry in Ephesus (Acts 20:31). Reddy (2002: 83) states that this letter has two purposes which are as follows, "Firstly, it addresses the challenges that faced the Church at Corinth. Secondly, it offers guidance and instruction on a variety of questions about which the Corinthians had written. The first letter to 1 Corinthians was written for maintenance purposes." Paul fashioned the word for the church; the oral interpreter of Paul's letter (a compassionate emissary) gave that word its body in presentation before the community and "The creation of this new body can be viewed as a counter-performance to the effective recitations offered by Paul's rivals, which implicitly demeaned Paul's presentations. The effect of the performance was to re-establish Paul as a potent and powerful voice within the Corinthian community" (Ward, 1996, n.p.).

\section{Second Letter to Corinthians}

The Apostle Paul identifies himself as the writer (2 Corinthians 1: 1). The letter was written between CE 55-56 and while the apostle was in Philippi. This letter deals with the ministry within the church and also wants the believers to assist by contributing to the church in Jerusalem. The apostle also wrote to defend himself against the charges which were placed by his opponents.

\section{The Letter to the Galatians}

The Apostle Paul identified himself as the author (Galatians 1: 1) and was written in CE 57 from central Asia Minor. The Apostle Paul writes this letter also stating that when it came to Jewish practices and laws, non-Jews who converted to Christianity were no longer compelled to partake in such rituals. He also defends himself as an apostle to the Gentiles.

\section{The Letter to the Ephesians}

The Apostle Paul identifies himself as the author (Ephesians 1: 1). Written between CE 6062. "The initial greeting, then proceeding to doctrinal truth followed by the practical application then concluding with personal matters" (Reddy, 2002, 84). This city was famous as a commercial, political and religious centre. Many Christian leaders were from that city. On Apostle Paul's second missionary journey he established the church in Ephesus (Acts 18: 1821). This letter was addressed to the Saints. The letter highlights the relationship between Christ and His Church. 


\section{The Letter to the Philippians}

The author refers to himself as the Apostle Paul (Philippians 1: 1). Written around CE 60 and while he was still in prison (Thurston \& Ryan, 2009). He wanted to inform them of Timothy's visit and to also warn them about the Judaizers. Ample emphasis is also placed on the word joy, the word appears 18 times in this letter and is, consequently, the keyword. "Rejoice in the Lord always. I say it again: Rejoice!" (Philippians 4: 4).

\section{The Letter to the Colossians}

On three occasions the author identifies himself as Paul the Apostle (Colossians. 1: 1, 1:23, and 4: 18). Written around CE 68 and while he was in prison. Written to prompt a prayerful awareness in the spiritual progress of the followers. According to Reddy (2002: 85) "To combat false teachings as well as make known the new nature of a new life in Christ, together with its demands on the Christian. The Apostle Paul makes known that Jesus Christ is supreme over everything. Believing in the death and resurrection of Christ is all that the believer needs to save him/her from his/her sins. To exhort the believers to live a life of which is holy." Ephesians looks at the oneness in Christ and Colossians looks at one's completeness in Christ. This letter projects to its audience that in Christ they are complete.

\section{The First Letter to the Thessalonians}

This letter was written by the Apostle Paul to new believers and was written around CE 51 . Both his Thessalonians letters were among the first he wrote. Written communication is used by the apostle to commend the believers that whilst they were being persecuted their faith in Christ was steadfast. In this letter, he also presented Jesus Christ's deity and Lordship.

\section{The Second Letter to the Thessalonians}

This letter was written between CE 51-52. The Apostle Paul wrote to the same audience twice and it is a continuation of his initial letter. However, Pauline's authorship regarding this letter is questioned. Reddy (2002: 86) states that "Paul writes to warn Christians about neglecting their everyday life because of their expectation of the Second Coming of Christ." Even though the believers were focusing on the return of Christ the Apostle Paul did not want them to disregard the responsibilities and duties in their everyday life. The Apostle Paul did not want to instill a pattern of indifference to everyday responsibilities and duties, etc.

\section{The First Letter to Timothy}

The Apostle Paul identifies himself as the author (Timothy 1:1). Written around CE 65 to the Apostle Paul's understudy known as Timothy. Timothy became a Christian on Apostle Paul's first missionary. The Apostle Paul wrote three letters to his understudies, Timothy and Titus. First and Second Timothy and Titus and each is also known as a pastoral letter. He guides Timothy on how he should go about having oversight and care for the churches under his care. At the time that the Apostle Paul wrote to Timothy and Titus, they were already established in the ministry as elders/pastors. According to Reddy (2002: 86) "There is doubt that this letter was intended for public communication, specifically the Ephesians church." It can be concluded that this letter clarifies how Christians should live and how Christian leaders should behave themselves (Reddy, 2002).

Stamps (1990: 453) states the threefold purpose letter to Timothy:

Firstly, to encourage Timothy in regards to his personal life and ministry. Secondly, to urge him to protect the spotlessness of the gospel and its consecrated values from dishonesty by deceitful teachers. Thirdly, to offer him directions on matters related to the church and problems experienced at Ephesus. 


\section{The Second Letter to Timothy}

Written around CE 67. The Apostle Paul identifies himself as the author (2 Timothy 1: 1). Once again The Apostle Paul urges his understudy to guard the gospel and preach the word of God, endure hardship, and fulfill his charge. Believed to be written before his martyrdom. This could be seen as a mentoring letter.

\section{The letter to Titus}

Written around CE 55-56. The Apostle Paul identifies himself as the author (Titus 1: 1). In this letter, the theme is sound doctrine and good works. Stamps (1990: 447) mentions this letter's fourfold purpose as, "setting in order what Paul had left unfinished in the churches of Crete, including the appointment of elders (Titus 1:5). Secondly, assisting the churches to grow in faith, in the knowledge of the truth, and godly living (Titus 1:1). Thirdly, to the silencing of false teachers (Titus 1: 11). Finally, for Titus to come to Paul after he is relieved by Artemas or Tychicus (Titus 3: 12)."

\section{The Letter to Philemon}

The Apostle Paul wrote this letter to Philemon between CE 57-62. It is about Onesimus who is the runaway slave of Philemon. Paul thus uses slavery as opposed to freedom in language more often in his writings as a metaphor (Foster, n.d.). He was requesting that Philemon accept Onesimus back as a brother in the Lord and not as a slave. It is considered to be a prison letter, which may have been co-authored by Paul the Apostle with Timothy, to Philemon, a leader in the Colossian church. Onesimus came into interaction with Paul, and may have been arrested and imprisoned together with Paul. On the other hand, he may have previously heard Paul's name (as he was owned by a Christian) and then went to him for help (O'Brien, 1982).

\section{Communication characteristics identified in the life of the Apostle Paul}

Roach (n.d.: n.p.) states the seven skills which the Apostle Paul practiced were through his ability as an astutecommunicator which are as follows.

He was:

- Able to connect with a group outside of his culture.

- Able to connect with the intellectual élite.

- Gifted to engage non-believers in the gospel message by referring to the evidence of nature and a supernatural creator.

- Able to appeal to their desire to worship the things that point to God.

- Skilled to talk with people in the marketplace outside of a temple building.

- Able to speak to them on their terms.

- Gifted enough to use the quotes from their writers and philosophers to convey the message of the gospel.

\section{Conclusion}

The Apostle Paul was a trained Jewish Scholar in the law and was able to be a defender of the gospel of Jesus. Due to his Jewish upbringing, Paul learned the Scripture from a very early age. He used different forms of communication that were available to him during his era. Among the forms of communication that were available to him at the time were verbal communication, downward, upward, lateral, small group communication, public speaking. When looking at the Apostle Paul as a communication scientist, he was an expert tactician in transmitting information, accuracy, and leadership (Roach, n.d.). He was also a prolific writer as can be concluded from a close examination his letters. He has written more books than anyone else in the Holy Bible. Pauline Letters were likely collected and dispersed for general church use by the end of the $1^{\text {st }}$ Century or just subsequent to that. A follower of Paul, perhaps 
Onesimus, may even have used Ephesians as a covering letter for the whole collection. Paul discusses spiritual gifts and public worshipand also stressed the communal aspect of the church and in his works regarded the resurrection as a joint phenomenon in the expectation of an end-time resurrection from the dead, with Jesus Christ as the first fruits of all those who have died. Paul was clearly the right man in the right place and time. He was always wellprepared and was essentilally well-educated for his role as a spreader of the 'good news'. He wrote and used his oratorical skills exceptionally well and always arrived at the same simple message of who Jesus Christ is, why He came, how He died, and how He resurrected from the dead. His knowledge of the world is obvious from his aptitude to quote the key philosophers of his day and with his immense understanding of the Graeco-Roman world he was able to effectively communicate with the learned Greeks of Corith and elsewhere. He displayed great understanding of the many issues facing society (Murphy O'Connor, 2008).

Had the Apostle Paul been alive today the reseracher strongly believes that he would have extensively used social media to its fullest to maintain and propagate the gospel of Christ. This would have enabled him to reach a much larger audience. Who would have thought that the most learned of Pharisees would eventually become the greatest apostle of the gospel of Christ? He used his skills and training to preach, teach and write to maintain and propagate the gospel of Jesus Christ as a faithful and dedicated servant. "The Gospel . . . is the power of God for salvation to everyone who has faith, to the Jew first and also to the Greek. For in it the righteousness of God is revealed through faith for faith" $(1: 16-17)$. Paul took decisive action and made a great effort to learn about the people he was speaking to and their diverse cultures. He consequently forged strong linkages wuth all with whom he came into contact.

\section{References}

Cleary, S. (2017). Jesus and the Religious Leaders. Bible.org. ( [Available online at https://bible.org/seriespage/48-jesus-and-religious-leaders. Accessed on 5 August 2017.

du Toit, A.B. (1985). Guide to the New Testament. Vol. 5. Pretoria: NG Kerk Boekhandel (Edms) Bpk.

du Toit, A.B. (1988). Guide to the New Testament. Pretoria: NG Kerk Boekhandel (Edms) Bpk.

Foster, P. ( ) Philippians And Philemon: Sacra Pagina Commentary.

Hornby, A.S. (Ed.). (2000). Oxford Advanced Learner's Dictionary of Current English 6th Edition.

Kim, Y-S. (2011). A Theological Introduction to Paul's Letters, Eugene, Oregon: Cascade Books.

Ludlow, V. L. (1975). Major Jewish groups in the New Testament. [Available online https://www.lds.org/ensign/1975/01/major-jewish-groups-in-the-new-testament?lang =eng]. Accessed on 6 August 2017.

Mc Gee, J.V. (N.D). Thru the Bible Radio. California: Pasadena.

Mishra, S. (2017). Shannon and Weaver Model of Communication. [Available online https://www.businesstopia.net/communication/shannon-and-weaver-model-communication]. Accessed on 2 January 2021.

Murphy-O'Connor, J. (1995). Paul the Letter-Writer: His World, His Options, His Skills. Collegeville, MN: Liturgical. 
Murphy-O'Connor, J. (2008). Keys to First Corinthians: Revisiting the Major Issues, Oxford: OUP, 20-31..

O'Brien, P. (1982). Colossians, Philemon. Word Biblical Commentary. Word Books.

Petruzzello, M. (n.d.). St. Paul's Contributions to the New Testament. Britannica. [Available online at https://www.britannica.com/list/st-pauls-contributions-to-the-new-testament]. Accessed on the 1 August 2021.

Richards, E.R. (2004). Paul and First-Century Letter Writing: Secretaries, Composition and Collection. Downers Grove, IL; Leicester, England: InterVarsity Press.

Reddy, M.M. (2021). The Apostle Peter communicating his divinely inspired message to the Jews. ISSN 2414-3324 online Volume 102. Pharos Theological Journal, 102,1-12.

[Available online at https://www.pharosjot.com/uploads/7/1/6/3/

7163688/article_32_vol_102_2021_unizul_.pdf].

Reddy, M.M. (2018). The forms of communication used by the early Christian church. Vol. 73 | No. 8 | Aug 2017. International Journal of Sciences and Research. Pp. 181-195.

Reddy, M.M. (2018). The use of written communication by the early Christian leaders: for maintenance and the propagation of Christianity. Pharos Journal of Theology. ISSN 24143324 online Volume 99, 1-13. [Available online

https://www.pharosjot.com/uploads/7/1/6/3/7163688/article_5_vol_99_2018_reddy__unizul.pdf].

Reddy, M.M. (2004). Communication in Christian Groups from Movements to Organisations. Unpublished dissertation. Doctorate in Literature. University of Zululand.

Reddy, M.M. (2002). Communication for Maintenance and Propagation: The forms of communication used by the cell church as an emerging organisation. Unpublished thesis. Master of Arts. University of Zululand.

Reed, D. (2016). The priesthood who were the religious leaders of Jesus's day? Thorn crown journal. [Available online at http://www.thorncrownjournal.com/ timeofchrist/religiousleaders.html]. Accessed on 6 August 2017.

Roach, D. (n.d.). 7 Best Communication Characteristics of the Apostle Paul

Like $A$ Team. [Available online at https://likeateam.com/7-best-communicationcharacteristics-of-the-apostle-paul/]. Accessed on 5 August 2021.

Rogers, Everett V., and Agarwala-Rogers, Rekha. (1976). Communication in Organisation. New York: The Free Press.

Ruden, S. (2010). Paul Among the People: The Apostle Reinterpreted and Reimagined in His Own Time, Pantheon.

Shannon and Weaver Model of Communication. (n.d.). [Available online at https://www.communicationtheory.org/shannon-and-weaver-model-of-communication/].

Accessed on the 10 July 2021.

Spencer, A.B. (2016). 'A style study of the Apostle Paul's communication with Festus and Agrippa: The use of literary Koine Greek in Acts 25:14-22; 26:1-29', In die Skriflig/ln Luce Verbi. 50(4), a2017 DOI: https://doi.org/10.4102/ids.v50i4. 2017. Accessed on the 15 October 2021.

Stamps, D. C. (1990). The Full Life Study Bible - NIV. Florida: Life Publishers International. 
Taylor, C. \& Talyor, J. (2016). The bible journey. [Available online at http://www.thebiblejourney.org/biblejourney1/21-the-romanojewish-world-of-thenewtestament/jewish-religious-leaders/]. Accessed on the 6 August 2017.

Stowers, S. K. (1989). Letter Writing in Greco-Roman Antiquity. Library of Early Christianity, Vol. 8. Ed., Wayne A. Meeks, Philadelphia: Westminster.

Tenny, M. (1975). The Zondervan Pictorial Encyclopedia of the Bible. Michigan: Zondervan Publishing.

Tenny, C. C. (1978). New Testament Survey. Michigan: Eerdmans Publishing Company.

Thurston, B.B. \& Ryan, J. (2009). Philippians and Philemon (Volume 10), Harrington, D.J., Sacra Pagina

Tubbs, S. T. \& Moss, S. (1978). Interpersonal Communication. New York: Random House.

Ward, R.F. (1996). Pauline Voices and Presence as Strategic Communication. Reformed Liturgy and Music 30:2. [Available online at https://www.religion-online.org/article/paulinevoices-and-presence-as-strategic-communication/]. Accessed on the 12 October 2021. 